\title{
Hindistan'da Türkçe öğretimi, Türk Dili ve Edebiyatı programı
}

\section{Mohd MANAZİR1}

APA: Manazir, M. (2019). Hindistan'da Türkçe öğretimi, Türk Dili ve Edebiyatı programı. RumeliDE Dil ve Edebiyat Araşturmaları Dergisi, (Ö6), 53-544. DOI: 10.29000/rumelide.648416

\section{$\ddot{\mathbf{O} z}$}

Hindistan-Türkiye ilişkileri çok eskiye dayanmaktadır. Yaklaşık sekiz asır Hindistan'ı vatan tutan Türkler birçok edebi ve mimari eser bırakmıştır. Sekiz asır Türk hakimiyetinde kalan ve kültürel çeşitlilikte Anadolu'yla yarışabilecek durumda olan Hindistan, Türk kültüründen oldukça etkilenmiştir. Bu etkiye Hindistan'da konuşulan Hintçe ve Urduca'da daha çok rastlanır. Türkçe her ne kadar Hindistan'ın resmî dili olarak kabullenilmemişse de kendi tesirini Urduca ve Hintçe'ye bırakmıştır. Bugün Hintçe, Urduca ve Türkçe arasındaki ortak kelimelerin sayısı dokuz bin civarına varmaktadır. Fakat İngilizlerin Hindistan'a girişiyle Türkçe Hindistan'da unutulmuş ve Türkçe eserlerin çoğu İngiltere’ye götürülmüştür. Kalan eserler üzerinde de yeterince ilmî çalışma yapılmamıştır. Fakat Delhi'deki Jamia Millia İslamia Üniversitesinde TİKA ve Yunus Emre Enstitüsü’nün 2006'dan beri ortaklaşa yürüttüğü Türkçe programı ile Türkçenin yaygınlık kazanması hedeflenmiştir. Jamia Millia İslamia Üniversitesinde, Türkçe öğretimi, TİKA’nın girişimleri sonucu, 2006-2007 öğretim yılında başlamıştır ve 2010 yılından bu yana da Yunus Emre Enstitüsünün desteği ile devam etmektedir. Beşeri Bilimler ve Yabancı Diller Fakültesi çatısı altında, sertifika programı kapsamında açılan kurslar, takip eden süreçte, sırasıyla Diploma ve Yüksek Diploma programları ile ivme kazanmıştır. Yukarıdaki programlara öğrenciler tarafından gösterilen ilgi neticesinde, 2012-2013 öğretim yılında Türk Dili ve Edebiyatı lisans programı açılmış ve ilk öğrenci kayıtlarını almıştır. Üzerinde çalıştığımız makalede; 2006'da Jamia Millia İslamia Üniversitesinde sertifika programı ile başlayan, bugün lisans düzeyinde olan ve yüksek lisans programının açılması yönünde ilerleyen bölümün gelişimi üzerinde durulacaktır. Ayrıca Hindistan'ın Delhi eyaletindeki bir başka üniversite olan Jawaharlal Nehru'da da Yunus Emre Enstitüsünün protokolü çerçevesinde seçmeli Türkçe dersleri mevcuttur ve makalemizde Arapça, İngilizce, Farsça gibi dil ve edebiyat bölümlerinde okuyan öğrencilerin Türkçeyi tercih etme sebepleri de ele alınacaktır.

Anahtar kelimeler: Hindistan-Türkiye ilişkileri, Türkçe öğretimi, Türk dili ve edebiyati bölümünün açılması ve gelişmesi.

\section{Abstract \\ Teaching Turkish in India, Turkish language and literature}

India and Turkey relations are based on very old. The Turks who held İndia for almost eight centuries, left many literary and architectural works. India, which remained under Turkish rule for eight centuries and could compete with Anatolia in cultural diversity, was highly influenced by Turkish culture. This effect is more common in Hindi and Urdu spoken in India. Although Turkish was not accepted as the official language of India, it left its influence on Urdu and Hindi. Today, the number of common words between Hindi, Urdu and Turkish is around nine thousand. However, with the

1 YL Öğrencisi, Necmettin Erbakan Üniversitesi, Sosyal Bilimler Enstitüsü, Türk Dili ve Edebiyatı ABD (Konya, Türkiye), manazirm348@gmail.com, ORCID ID: 00oo-0002-1748-2531 [Makale kayt tarihi: 06.10.2019-kabul tarihi: 20.11.2019; DOI: $10.29000 /$ rumelide.648416] 
arrival of the British in India, Turkish was forgotten in India and most of the Turkish works were taken to England. There are not enough scientific studies on the remaining works. However, the Turkish program at Jamia Millia Islamia University in Delhi, which has been carried out jointly by TIKA and Yunus Emre Institute since 2006, aims to expand Turkish. At the Jamia Millia Islamia University, Turkish teaching started in the 2006-2007 academic year as a result of TIKA's initiatives and has been continuing since 2010 with the support of the Yunus Emre Institute. The courses opened within the scope of the Certificate program under the umbrella of the Faculty of Humanities and Foreign Languages gained momentum with the Diploma and Higher Diploma programs, respectively. As a result of the interest shown by the students to the above programs, the undergraduate program of Turkish Language and Literature was opened in the 2012-2013 academic year as a result of TIKA's initiatives and has been continuing since 2010 with the support of the Yunus Emre Institute. The courses opened within the scope of the Certificate program under the umbrella of the Faculty of Humanities and Foreign Languages gained momentum with the Diploma and Higher Diploma programs, respectively. As a result of the interest shown by the students to the above programs, the undergraduate program of Turkish Language and Literature was opened in the 20122013 academic year and the first student enrolled. In the article we are working on; it will focus on the development of the department that started with the Certificate program at Jamia Millia İslamia University in 2006 and is currently at the undergraduate level and proceeding to open the graduate peogram. In addition, Jawaharlal Nehru, another university in the state of Delhi in India, offers elective Turkish courses in accordance with the protocol of the Yunus Emre Institute, and the article will also examine the reasons why students of Arabic, English and Persian language prefer Turkish.

Keywords: India-Turkey relations, teaching Turkish, opening and development of the department of Turkish language and literature.

\section{Giriş}

Dünyanın en gelişmiş uygarlıklarının beşiği olan Hindistan'da zamanla çeşitli devletler kurulmuştur. Fakat Hindistan'a en çok tesir eden Türk devletleri olmuştur. Bunun en önemli sebebi de halka eşit davranmaları, din ve dil bakımından insanlar arasında ayrımcılık yapmamalarıdır. Hint Raçputların (Hint Racalıklar) ise kast sisteminde ayrım yapması Türk hükümdarları için Hint topraklarında hakimiyet kurma işini kolaylaştırmıştır. Çünkü Raçputlar, ataerkil düşüncesine sahip; üstelik halka karşı hoşgörülü olmaması da Hint halkının Türk Sultanlığına meyletmesinde önemli bir amil olmuştur. Gerek Gazneli Mahmud (öl. 1030) olsun gerekse Babür Şah (öl. 1530) veya ondan sonra gelen sultanlar olsun Hindistan'ın ekonomisini güçlendirmekte büyük çaba göstermişlerdir. Ekonomi dışında her sultan kendi döneminin şartlarına uyarak kaldığı müddette medrese, hangâh, cami, türbe, saray ve efsanevi Tac Mahal'in yanı sıra pek çok mükemmel eser inşa etmiştir. Mimari dışında edebî eserlerin sayısı da az sayılmaz. Kalküta, Mumbai, Delhi ve Haydarabad gibi muhtelif yerlerin kütüphane ve müzelerinde el yazmaları bulunmaktadır. Mevcut eserler içerisinde Anadolu-Osmanlı sahasına ait eserlerin sayısı önemli bir yer tutmaktadır. Ancak Çağatay Türkçesi'yle yazılmış eserler de dikkat çekicidir. Fakat bu eserler üzerine bilimsel çerçevede yeterli çalışma bulunmamaktadır. Bu yüzden dile ilgi duyan ve Fars Dili ve Edebiyatı Bölümünde öğretim görevlisi olan hocalar Jamia Millia İslamia Üniversitesi (Delhi, Hindistan)'da “Türkçe öğretimi” adlı bir projeyle üniversite senatörleriyle görüşmüşler. Diğer taraftan Türkiye'nin de böyle bir projesinin olması bu işin kolaylaşmasını sağlamıştır. 2006'da "Sertifika" programıyla Hindistan'da Türkçe öğretim programı başlamıştır. Bu bölümün başlangıcında öğrenim gören 4-5 öğrenciydi ancak halihazırda bu bölümde 184 öğrenci kayıtlıdır. Bu makalede ilk önce Hindistan ve Türkiye'nin ilişkileri ve kültürel mübadeleden söz edilecek 
ve daha sonra Hindistan'da Türkçe öğretimi ve onun gelişmesi üzerine durulacaktır.Sonuç ve kaynakça kısmıyla makale sonlandırılacaktır.

\section{Hindistan-Türkiye ilişkileri}

Hindistan-Türkiye arasındaki ilk diplomatik ilişkiler 1481-82 yıllarında Osmanlı padişahları ve Müslüman liderler arasında gerçekleşmiştir. Hindistan'ın özgürlük savaşçısı Dr. Mukhtar Ahmet Ansari’nin 1912'de Balkan savaşındaki tıbbî misyonu ile Türkiye-Hindistan ilişkisi daha da güçlü bir ivme kazanmıştır. Millî Mücadele yıllarında Türkiye Cumhuriyetinin kurulması için Hint desteğinin gelmesi, Osmanlı devletine dayalı Hindistan'da hilafet hareketinin başlaması Mahatma Gandi'nin bizzat buna destek vermesi de Hint-Türkiye ilişkisini gözler önüne sermektedir (İndia-Turkey relation 2014: 1-2). Birinci Dünya Savaşı'nda Türkiye İngiltere'ye karşı Almanya'ya destek oldu. Hint Müslümanları Türkiye'nin savaşa girmesinden dolayı çok tedirgin oldu. Çünkü İngilizler kazandığı takdirde Türkiye'ye karşı dürüst, adaletli davranmayacaklarını biliyorlardı. Hatta Hint Müslümanları İngiltere Başbakanı LIoyd George'a yardımda bulunmak için Müslümanların mukaddes mekanlarına zarar verilmemesine dair ve cenkten sonra Müslümanların hilafetinin devam etmesine yönelik sözleşme yaptılar. Bu savaşta zafer İngiltere'nin eline geçtikten sonra İngilizler Hint Müslümanlarına verdiği sözleri tutmadı. Bundan dolayı Hint Müslümanları onlara sözlerini hatırlatmak ve hilafeti korumak için "Hilafet Hareketi”ni başlatmış ve bu hareket esnasında hem Devlet-i Osmaniyeyi desteklemek, hem de cenkte şehit olan ailelerin yetim çocuklarına maddi yardımda bulunmak maksadıyla yardım toplayarak yollamışlardır. (Urdu gazete 9. 03. 2018). Müslümanların Hindistan topraklarına ilk girişi VII. yüzyll gibi erken bir tarihe denk gelmektedir fakat bu dönemlerde Hindistan'da Müslüman hükümdarların etkisi zayıftı. Ancak XI. yüzyıldan sonra Hindistan adeta Müslüman Türklerin hücumlarının merkezine dönmüştür (Bokuleva, 2012: 442). Özellikle 1000-1027 ylları arasında Sultan Gazneli Mahmut'un Hindistan'a 17. sefer düzenlemesi ve onun Hindistan'a gelmesi Hinduların zihninde derin izler bırakmıştı. Gazneliler'in seferlerinden yaklaşı 150 yıl sonra ikinci bir Türk dalgası; Gur Sultanı Muhammed tarafından gerçekleştirildi (Malkoç, 2016:110-112). Hindistan coğrafyasında Delhi Türk Sultanlıkları 1206-1526, Kutbiler 1206-1266, Balabanlılar 1266-1290, Kalaç Sultanlığı 1290-1320, Tuğluklular 1320-1414, Seyyidîler 1414-1451, Lodîler 1451-1526, Babürler 1526-1858 olmak üzere tarih boyunca çeşitli Türk devletleri kurulmuştur. Bu devletler içerisinde en uzun süren Babür İmparatorluğudur. Fakat Babür ile Osmanlılar arasında ilişkilere dair pek bilgi bulunmamaktadır. Amma Babür'den sonra Ekber ve Cihangirler ile IV. Murad'ın mektuplaşmaları bilinmektedir. Babürlü elçiler ile Osmanlılar arasında karşlık hediyeler ve diyaloglar ta 18. yüzyılın sonuna kadar devam etmiştir. (Bilkan, 1998: 2-4). XII. yüzyllın sonundan 1526'ya kadar Delhi Türk Sultanlı̆̆ı hakimiyetini sürdürmüştür. Delhi Türk Sultanlı̆̆ı, dönemine ait pek çok mimari eser günümüze kadar gelememiştir. Günümüze gelenlerden bazıları ise harabe halindedir. 1193 yılında Gurlu Muhammed Delhi'yi sultanlığının başkenti yaptıktan sonra bu tarih Hindistan'da gerçek Türk-Müslüman mimarisinin başlangıç tarihi olmuştur. 11. yüzyıldan itibaren mimarlıktan edebiyata, sanattan yazıya İslamiyetin etkisi görülmeye başlanmıştır. Hindistan'da halen ayakta olan ve Türkler tarafından yapılan mimarî eserler Türklerin mimarlıkta çok zengin olduğunu işaret etmektedir. (Macun, 348-350). "Hindistan'daki edebî ve kültürel ortamın oluşmasında da Türk asıll mutasavvıf ve şairlerin payı oldukça büyüktür. Türklerin Hindistan'da hüküm sürdüğ̈̈ dönemlerde her ne kadar Farsça resmî dil olsa da az çok eser Çağatay dilinde de verilmiştir. Çağatay Türkçesi için Babür-name, Aruz Risalesi, Mübayyen ve Risale Validiye Tercümesi gibi eserler zikredilebilir" (Bilkan, 1998: 9-11). Türkçe her ne kadar Hindistan'ın resmî dili olarak kabullenilmemişse de kendi tesirini Urduca'ya, Hintçe'ye bırakmıştır. Araştırmalara göre Türkçe ve Hintçe-Urduca arasındaki ortak kelimelerin sayısı dokuz bin civarına kadar varır. Hindistan'ın pilavı ve sihk kebabı (şiş kebabı) da Hintler'e Türkler tarafından öğretilmiştir. Ayrıca Hindistan'da Türki Topi 
(Türk Şapkası) da çok meşhurdur. (Asif, 2017: 1). Bugün Hindistan coğrafyasında Türkçe el yazma eserlerinin bulunması da Türkçenin son yüzylla kadar etkisini sürdürdüğünü ortaya koymaktadır. Hindistan'ın U.P. eyaletinin Rampur şehrindeki Raza Kütüphanesi başta olmak üzere ülkenin çeşitli yerlerinde 15 kütüphane Türkçe el yazmaları barındırmaktadır. Bu yazmaların çoğu çalışmaya değerdir fakat bu eserleri bilim dünyasına sunmak oldukça zahmetli bir iş gibi görünmektedir. Bunda, bölgenin coğrafi ve siyasal yapısı yanında, nadir eserlere karşı var olan ilgisizlik de etkili olmuştur (Kardaş, s. 210). Hindistan kütüphanelerinde bulunan Türkçe el yazmaları ile ilgili düzgün bir katalog yapılmadığı için eserleri taramak oldukça zahmetli bir iş gibi görünmektedir ancak Ali Fuat Bilkan'ın yaptığı çalışma “Hindistan'da Gelişen Türk Edebiyatı” işinizi kolaylaştırır diye düşünüyoruz. Hindistan’da Türklerin sekiz asır kalmalarına rağmen şimdi Türkçe bilen bir avuç kadar insanın var olması da bilim adamlarının Türkçeye karşı ilgisizliğini göstermektedir. Ancak bu ilgisizliğin giderilmesi için 2006-2007'de Jamia Millia İslamia Üniversitesinde sertifika programı ile başlayan Türkçe programı bugün lisans öğrencilerini de içine almıştır. Yunus Emre Enstitüsü ve Hindistan'ın Jamia Millia İslamia Üniversitesinin ortaklaşa yürüttüğü çalışma kapsamında her sene 4-5 öğrencinin yükseköğretim için Türkiye'ye gelmek için tercihte bulunduğu görülmektedir. Bunun yanı sıra Yaz Okulu ve diğer programlar sayesinde Türkiye her yll bir önceki seneye göre daha fazla öğrenci çekmeyi başarmaktadır. Bizim bu çalışmamızda 2006-2007'de sertifika programı ile başlamış olan Türkçe programının bugün lisans düzeyine ulaşmış olmasının sebepleri ve Türk Dili ve Edebiyatı Bölümünün gelişmesi üzerinde duracağız. Her programı madde madde işlemeye ve bir başlık altına toplamaya çalışacağız.

\section{Türkçe Öğretimi, Türk Dili ve Edebiyatı Bölümünün açılması ve gelişmesi}

Kısa Tarihçe

Türk Dili Program Türleri

Sertifika (Certificate)

Diploma ( Diploma)

Yüksek Diploma (Advance Diploma)

Türk Dili ve Edebiyatı Lisans Programı (B.A.)

B.A. (Lisans) Programı Müfredatı

Yüksek Lisans

Yaz Okulu

Öğretim Elemanları

Programın Fakülte İçindeki Diğer Dil Programlarına Kıyasla Tercih Edilirlik Tablosu

Mezunlar Nerelerde İstihdam Ediliyor? İş Olanakları Nelerdir?

Seçmeli Yabancı Dil Dersi Olarak Jawaharlal Nehru'da Türkçe

\section{1) Kısa tarihçe}

Jamia Millia İslamia Üniversitesinde Türkçe öğretimi, TíKA’nın girişimleri sonucu, 2006-2007 öğretim yılında başlamıştır. 2010 yılından bu yana ise Yunus Emre Enstitüsünün desteği ile devam etmektedir. Beşeri Bilimler ve Yabancı Diller Fakültesi çatısı altında, Sertifika programı kapsamında açılan kurslar, takip eden süreçte, sırasıyla Diploma ve Yüksek Diploma programları ile ivme kazanmıştır.

Yukarıdaki programlara öğrenciler tarafından gösterilen ilgi neticesinde, 2012-2013 öğretim yllında Lisans Programı olarak, Türk Dili ve Edebiyatı açılmış ve ilk öğrencilerini kabul etmiştir. JMİ Üniversitesinde lisans süresi toplam üç yıldır. 2014-2015 öğretim dönemi itibarıla (Lisans 
programından) ilk mezunlarını vermiştir. Lisansın (istisnai bölümler dışında) 3 yıl olduğu üniversitede, yüksek lisans programı, öğrencilerin kariyer planlaması açısından büyük önem arz etmektedir. Yüksek lisans açılması yönünde çalışmalara başlanmış, üniversitenin yönetmelikleri çerçevesinde hazırlıklar sona ermiş olup bir yıl sonra açılması öngörülmektedir. İlgili Senato kararının olumlu yönde çıması durumunda, Türk Dili Koordinatörlüğü, 2020-2021 dönemi için, Yüksek Lisans Programına öğrenci kabul etmeyi hedeflemektedir. Üniversite içindeki genel yapıyı ve öğrencilerin algısını göz önünde tutarak şu söylenebilir ki, ancak böylece bölüm hüviyetini de tam anlamıyla kazanmış olacaktır.

Tablo 1A: Tarihçe

\section{Türk Dili ve Edebiyatı Programı}

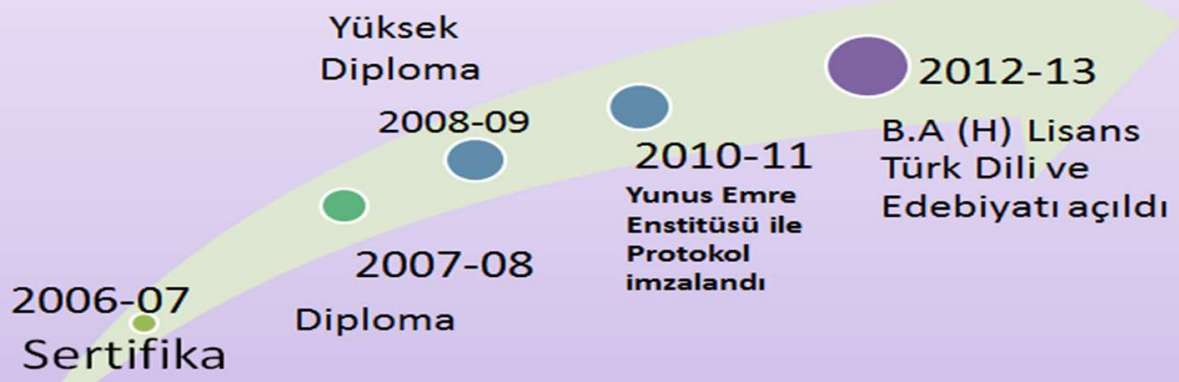

\section{2) Türk Dili Program Türleri}

\section{a) Sertifika}

Haftada üç gün ders verilen, çeşitli bölümlerde Lisans, Yüksek Lisans ya da Doktoraya devam eden öğrencilerin katıldı̆̆ı Türkçe öğretimi programıdır. Sertifika Programı sonunda başarılı öğrencilerin A2 seviyesinde Türkçe bilgisine sahip olması beklenir. 
Tablo 2A: Başvuru, kabul sayısı, yıllara ve cinsiyete göre öğrenci dağılımı

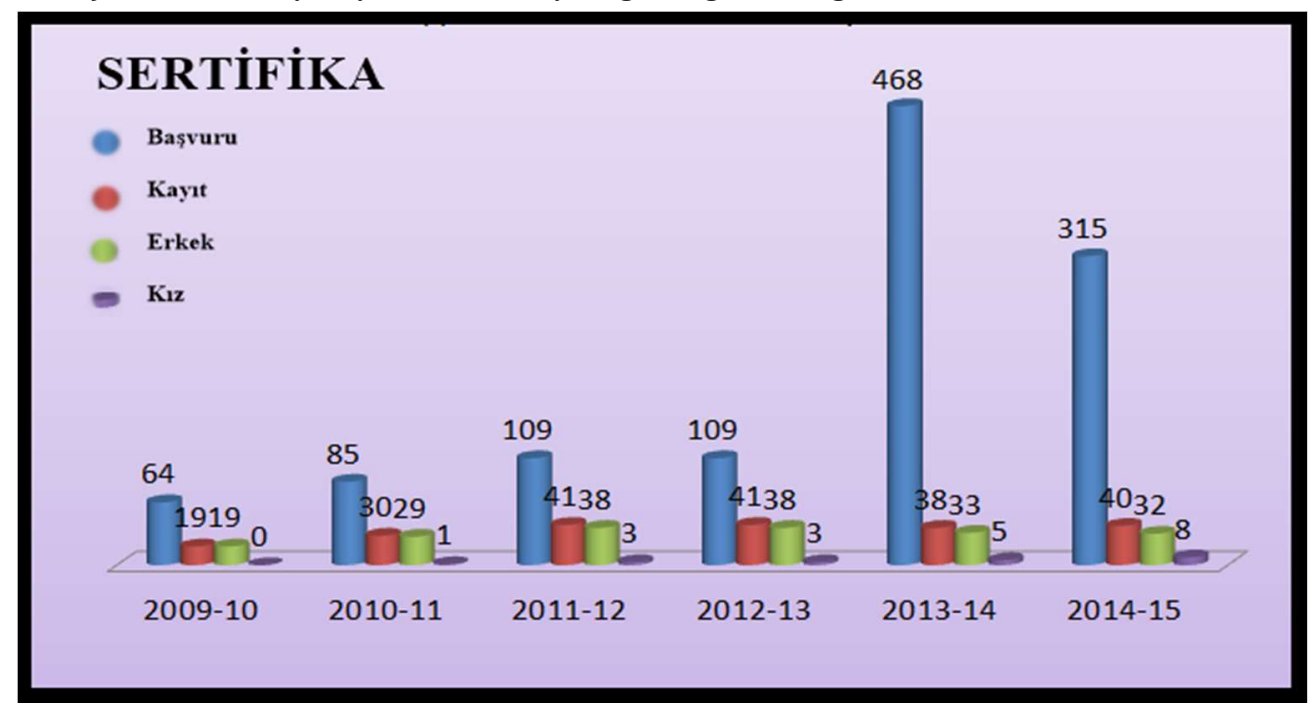

\section{b) Diploma}

Sertifika programını başarı ile tamamlamış öğrencilerin, yeni bir sınava girerek kabul edildiği, Türkçe öğretim programıdır. Bu programı tamamlayanların B2 seviyesinde Türkçe bilgisine sahip olması beklenmektedir.

Tablo 2B: Başvuru, kabul sayısı, yıllara ve cinsiyete göre öğrenci dağılımı

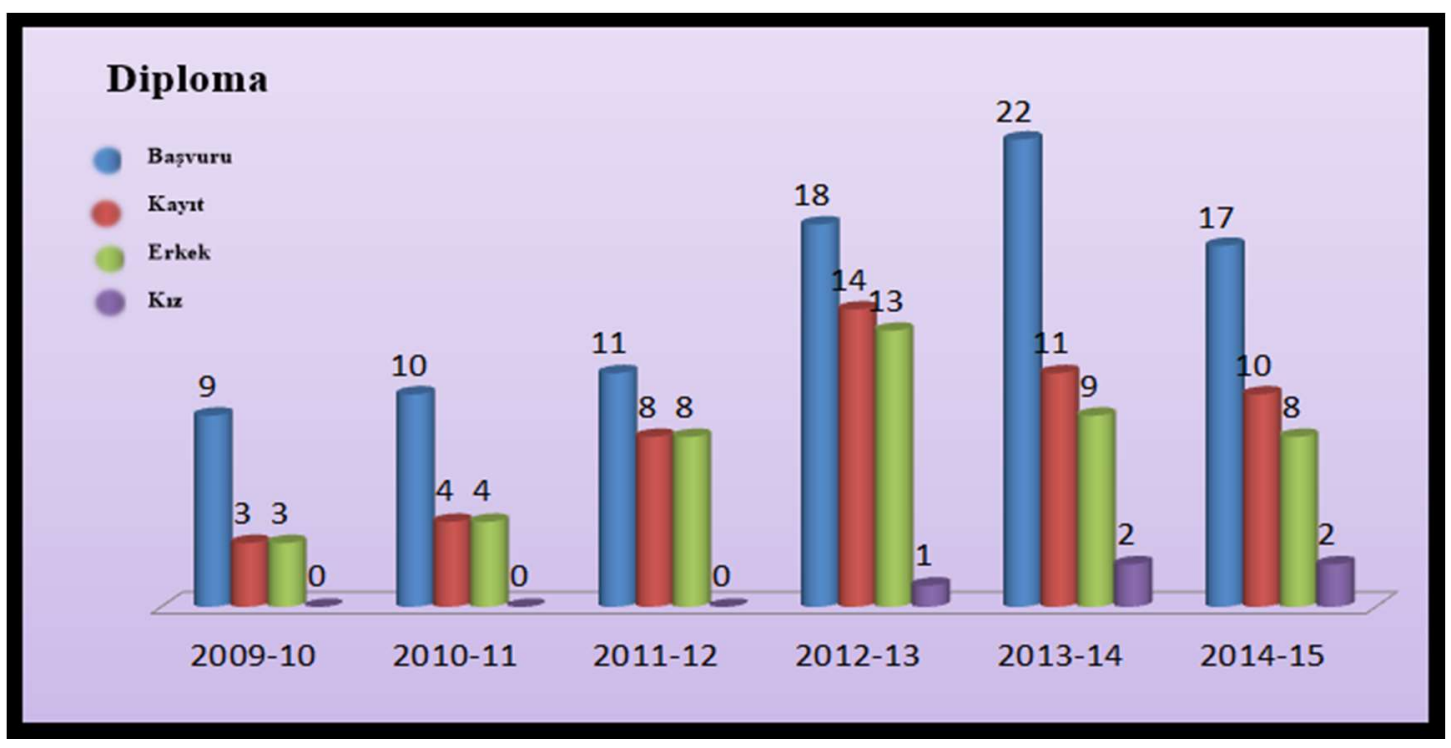

\section{c) Yüksek diploma}

B2 seviyesinde Türkçe bilgisine sahip öğrenciler, Gramer ve Metin İnceleme dersleri ile C1 seviyesine taşınırken, İngilizce-Türkçe çeviri dersleri, Türk Edebiyatında Öykü ve Şiir derslerini de alırlar. Yukarıdaki her üç program da haftanın sınırlı günlerinde, öğrencilerin diğer eğitim-öğretim faaliyetlerine engel olmayacak saatlerde planlanıp yürütülmektedir. Yüksek Diplomadan mezun olan bir öğrenci, Hindistan'da Lisans mezunu öğrencilerle aynı hak ve yetkilere sahip olmuş olur. Yukarıdaki program türlerinin, Türk dili dışında farklı dillerde de uygulandığı bilinmektedir. 
Tablo 2C: Başvuru, kabul sayısı, yıllara ve cinsiyete göre öğrenci dağılımı

\section{Yüksek Diploma}

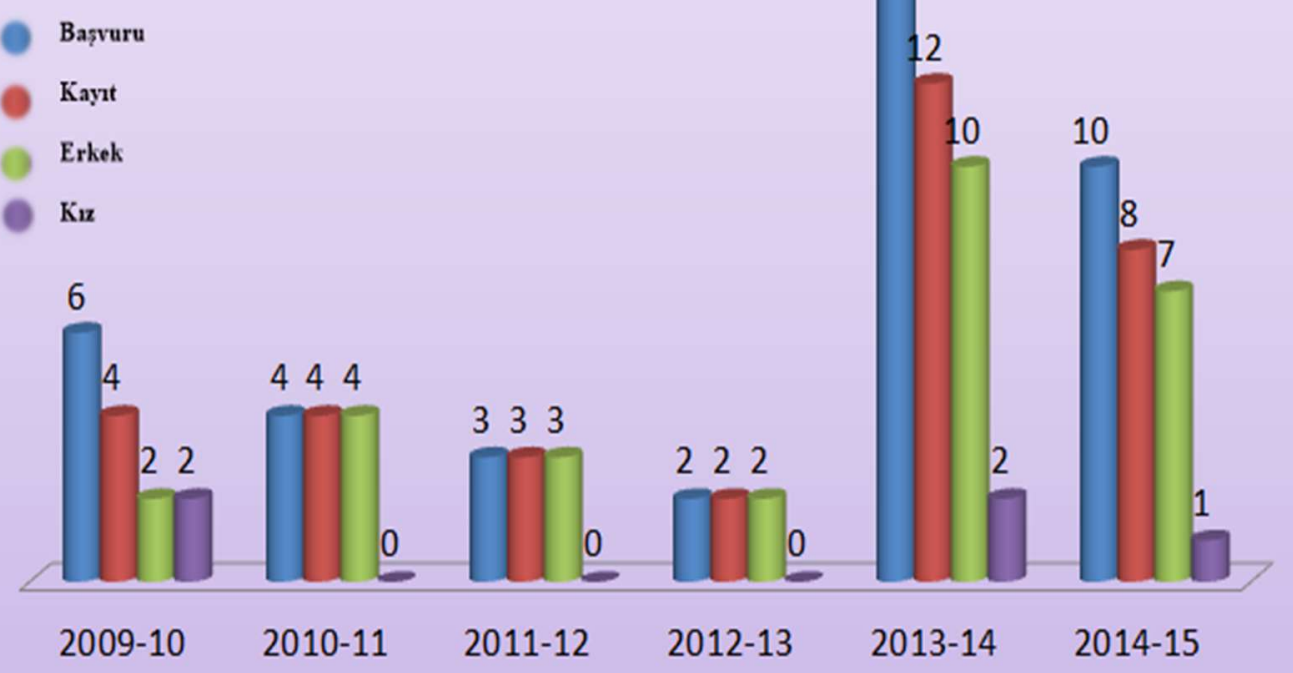

\section{d) Lisans programı}

Türk Dili ve Edebiyatı Lisans Programı, 3 sömestir Türkçe öğretimi ve 3 sömestir de dil ve edebiyat dersleri olmak üzere 3 yılda tamamlanır. Toplam 6 sömestirde verilen dersler aşağıdaki gibidir. Bölüm müfredatı için İngilizce isimler kullanılmaktadır, çalışmanız için önem arz edebilir diye, aynıyla aktariyorum.

\section{3) B.A. (lisans) programı müfredatı}

\begin{tabular}{|c|c|c|c|c|}
\hline 1st Year & & & & İçindekiler \\
\hline & Semester I & TR 101 & Turkish Language I & \\
\hline & & TR102 & Turkish Grammar I & \\
\hline & Semester II & TR201 & Turkish Language II & \\
\hline & & TR202 & Turkish Grammar II & \\
\hline \multicolumn{5}{|l|}{ 2nd Year } \\
\hline & Semester III & TR-301 & Turkish Language III & \\
\hline & & TR-302 & Turkish Grammar III & \\
\hline & Semester IV & TR-401 & $\begin{array}{l}\text { Turkish Literature in Republican Period } \\
\text { I }\end{array}$ & \\
\hline & & TR-402 & Ottoman Turkish I & \\
\hline \multicolumn{5}{|l|}{ 3rd Year } \\
\hline & Semester V & TR-501 & $\begin{array}{l}\text { History of Turkish Language \& Litreature } \\
\text { I }\end{array}$ & $\begin{array}{l}\text { Göktürk, } \quad \text { Uygur, } \\
\text { Karahanlı }\end{array}$ \\
\hline
\end{tabular}




\begin{tabular}{|l|l|l|l|l|}
\hline & TR-502 & Turkish Divan Literature I & \\
\hline & & TR-503 & Turkish Folk Literature & \\
\hline & & TR-504 & Modern Turkish Literature & $\begin{array}{l}\text { Tanzimat, Servet-i } \\
\text { Fünun, Fecr-i Ati }\end{array}$ \\
\hline & Semester VI & TR-601 & $\begin{array}{l}\text { History of Turkish Language \& Litreature } \\
\text { II }\end{array}$ & $\begin{array}{l}\text { Çăgatay, Kppçak, Eski } \\
\text { Anad. Turkish }\end{array}$ \\
\hline & & TR-602 & $\begin{array}{l}\text { Turkish Literature in Republican Period } \\
\text { II }\end{array}$ & \\
\hline & & TR-603 & National Turkish Litrary Movement & \\
\hline & & TR-604 & Divan Literature II & \\
\hline & & TR-605 & Sufi Literature & \\
\hline
\end{tabular}

Tablo 3A: Tercihlerinde Türk diline yer veren öğrenci sayısı (lisans başvuru), kabul sayısı, yıllara ve cinsiyete göre öğrenci dağılımı

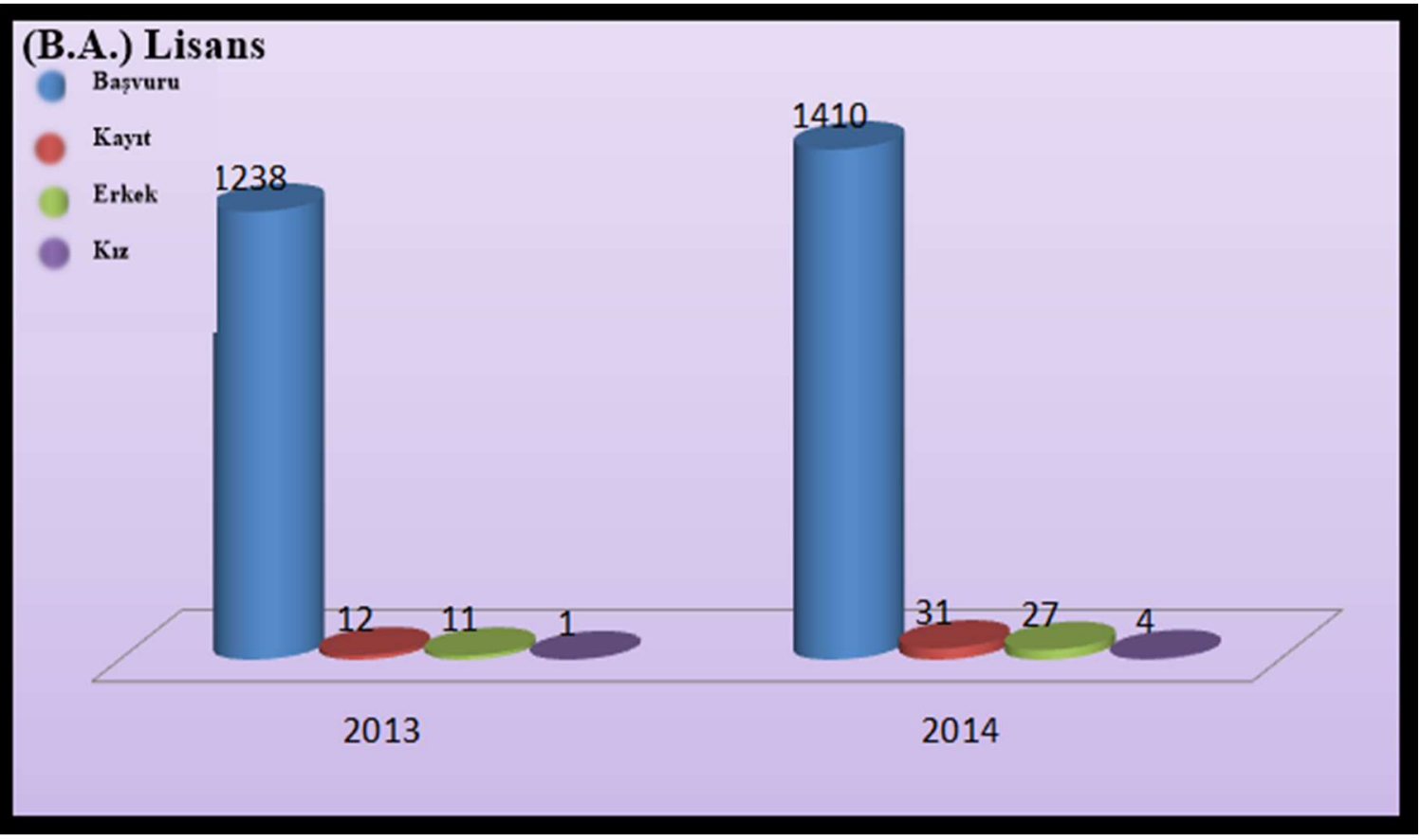

\section{4) Yüksek Lisans}

Bu bölümden mezun olup Türkiye'de Yüksek lisansını yapmak için öğrenciler Yurt dışı ve Akraba Topluluklar Başkanlığı (YTB) programına başvururlar. YTB uzman personeli tarafından yapılan mülakatlarda başarılı öğrenciler burs almaya hak kazanıp Türkiye'de okuma firsatı buluyorlar. Bu program sayesinde Hintli öğrencilerin bir kısmı Türkiye'nin çeşitli şehirlerindeki üniversitelerde 
öğrenim görürken bir kısmı da bitirip halihazırda JMİ'de öğretim görevlisi olarak görev yapmaktadır. Türkiye'de yüksek öğrenim gören bu öğrenciler Türkiye ile Hindistan arasında dostluk köprüsünü kurmakta büyük rol oynamaktadır. YTB projesi sayesinde ileride her iki ülkenin karşllık etkileşimleri daha da hizlanacaktır.

Tablo 4A: Yüksek Lisans kazanan öğrenciler

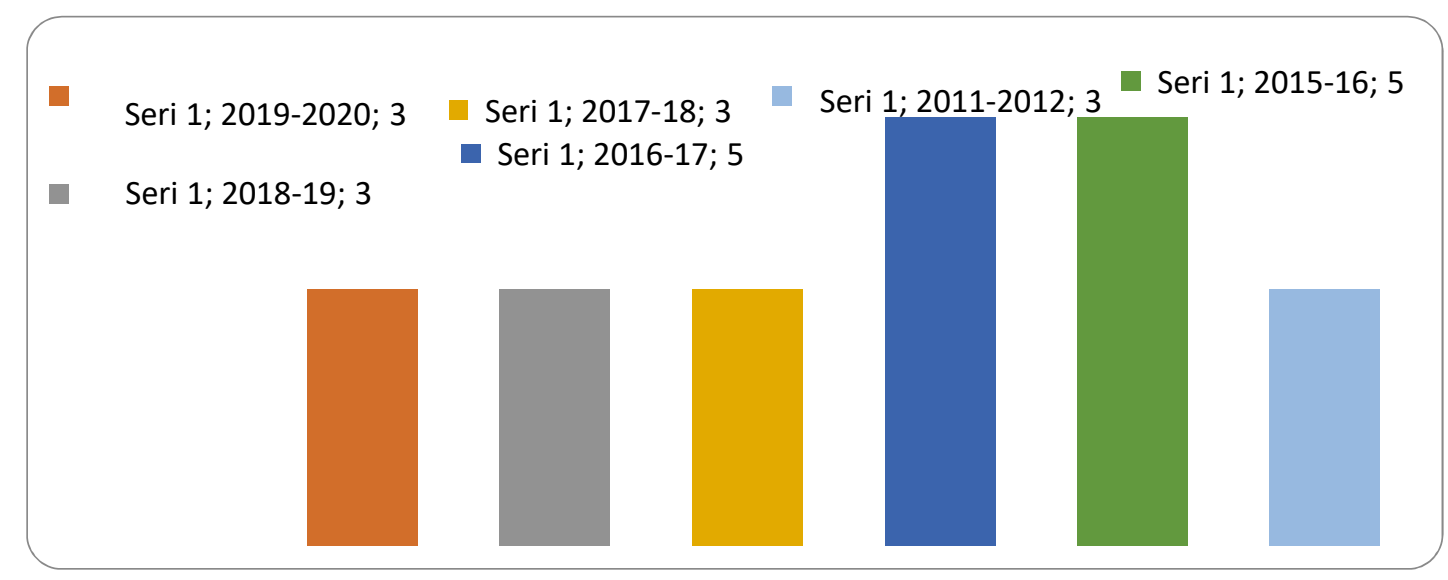

\section{5) Yaz okulu}

Yunus Emre Enstitüsü tarafından yürütülen Yaz Okulu Programı, her sene dünyanın dört bir yanından öğrencileri getirip Türkçe öğrenme, Türk kültürünü yakından tanıma fırsatı sunan bir programdır. Bu program, öğrencilerin Türkiye dışında diğer ülkelerin diline, kültürüne aşina olmaları gibi sosyal, duygusal ve yeteneksel gelişimlerine büyük bir katkı sunmaktadır. Öğrenciler bu program sayesinde hem yurt dışı tecrübesi kazanıp hem de bir kültür elçisi olarak ülkelerine dönmektedir. Program sırasında öğrencilere uzmanlar tarafından çok verimli dersler verilmektedir. Öğrenciler çeşitli faaliyetler yaparak kendilerini geliştirirler. Aynı zamanda bir ay verilen Türkçe dersleri Türkçe dışında ilgi alanlarını daha iyi anlayabilmek için ve kariyerlerine yönelik daha iyi plan yapabilmek için öğrencilere her türlü imkan sağlamaktadır. Bu öğrencilerin bir kısmı daha sonra Yüksek lisans yapmak için Türkiye'yi tercihte bulunmaktadır.

Tablo 5A: Yaz okulu kazanan öğrenciler

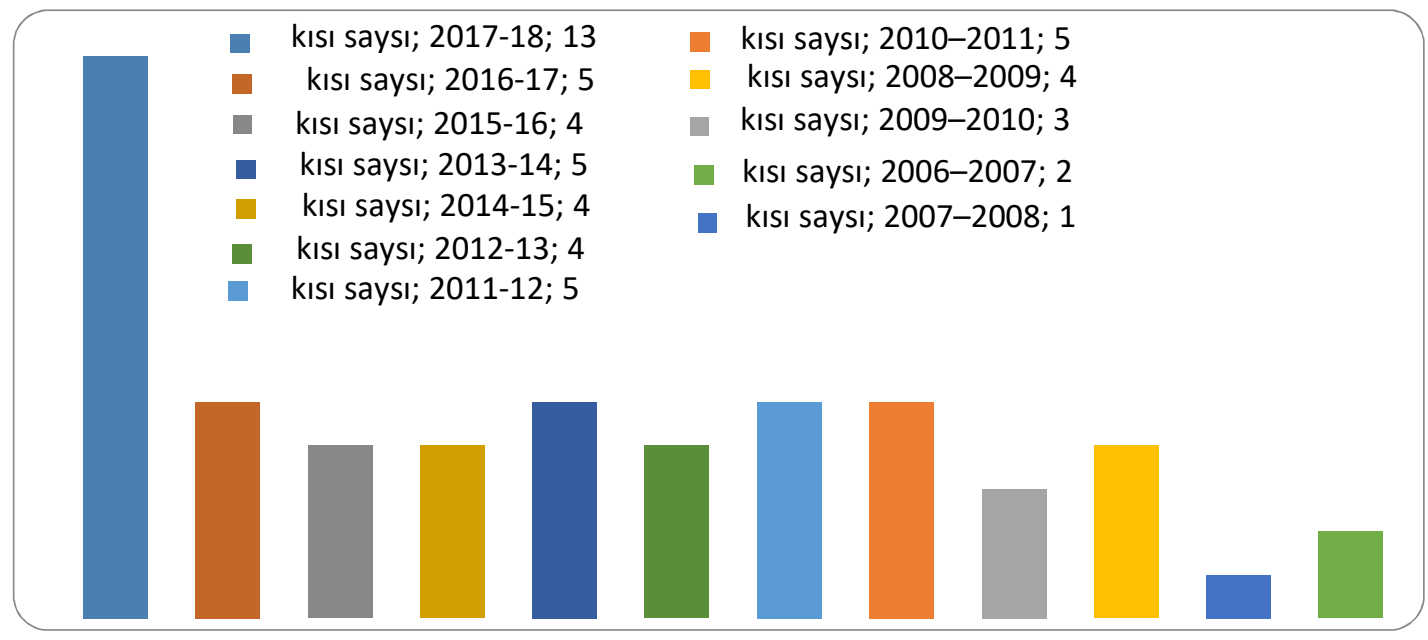




\section{6) Öğretim elemanları}

Bölüme her sene Türkoloji projesi kapsamında Yunus Emre Enstitüsü tarafından 3-4 Türk öğretim elemanı görevlendirilmektedir. Doktora düzeyinde Türkolog halihazırda yoktur. Ancak yüksek lisans açılması durumunda YEE'den talep edilecektir veya bu bölümden mezun olanların bir kısmı Türkiye'de doktoraların tamamlayıp bölüme hizmet edeceklerdir. 2017'de 2 öğrenci Türkiye'de Yüksek lisanslarını bitirip bu bölüme öğretmen olarak dönmüş, 2018'de bir öğrenci Yüksek lisansını tamamladıktan sonra bu bölümde göreve başlamıştır. Şu an bölümde üç yerli öğretmen görev yapmaktadır. Türkiye'den gelen öğretim elemanları genellikle her yıl değişmektedir. Bu hususta bölgede yaşamanın zorluklarının etken olduğu düşünülebilir.

Tablo 6A: Türkiye'den gelen öğretmen elemanlarının yıllara göre sayıları

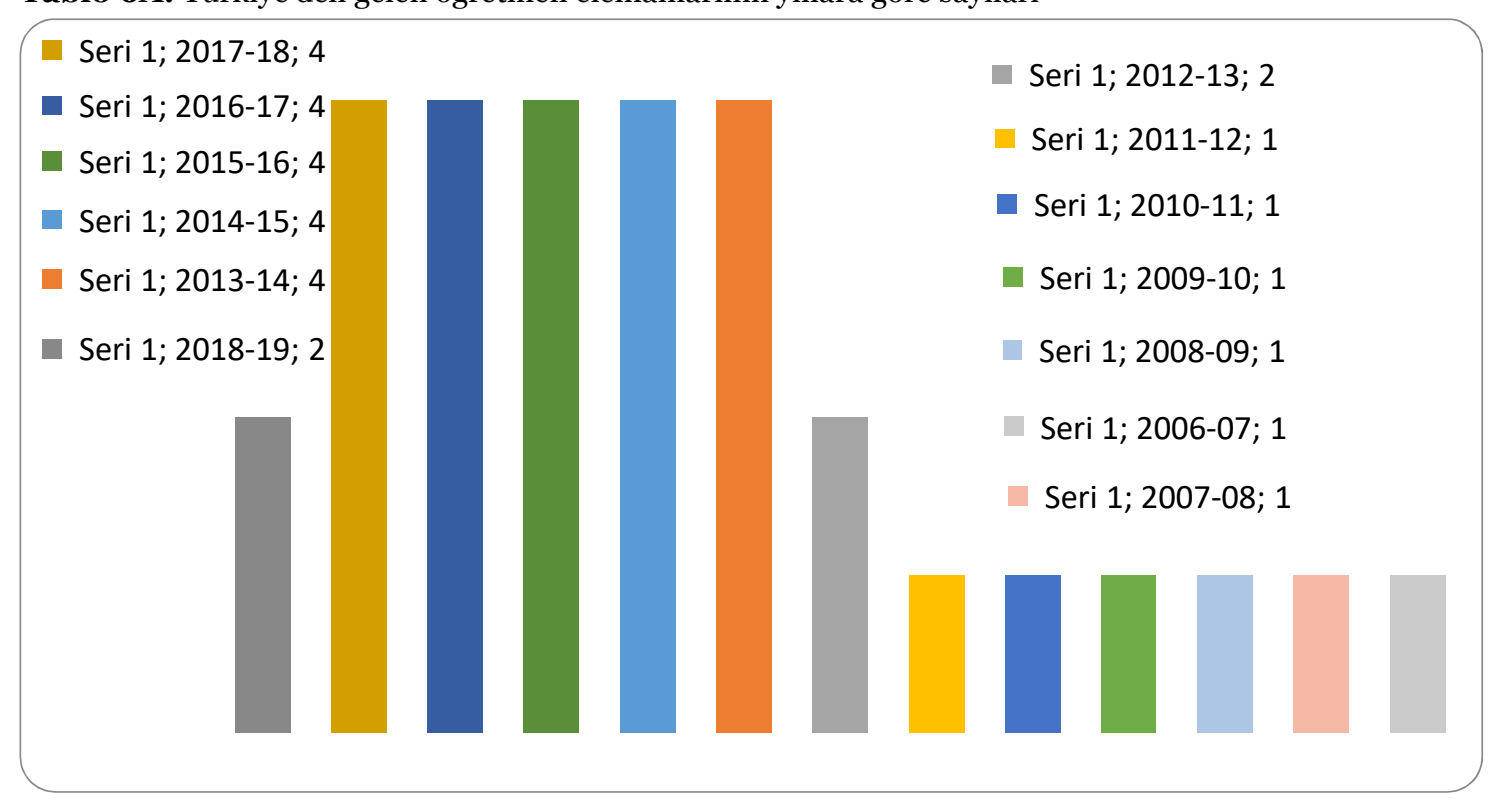

\section{7) Sayısal veriler işiğinda tercih edilirlik durumu}

Hindistan'da üniversiteler merkezî bir sınavla değil, her üniversite kendi içinde, ilgili fakültelerin yaptığı seçme sınavları ile öğrenci kabul etmektedir. Bu çerçevede Türk Dili ve Edebiyatı programı için tercihte bulunan öğrencilerin, Beşeri Bilimler ve Diller Fakültesi içindeki yüzdelik dilimi aşağıdaki gibidir. Elbette bir kısmı sınava girmiş, bir kısmı farklı üniversite ve bölümlerden kabul aldığı için belki hiç sınava girmemiş de olabilir. Fakat aşağıdaki tabloda söz konusu fakültedeki diğer bölümlerle birlikte Türk Dili ve Edebiyatı programının tercih edilirlik oranı, İngilizce'den sonra en çok tercih edilen bölüm olarak açıkça görülmektedir. Programın cazip olmasında mezuniyet sonrasında iyi koşullarda istihdam olanakları ve Türkiye burslusu olarak Türkiye'de yükseköğretime devam edebilme beklentisi de etkili olmaktadır. 
Tablo 7A: Tercih edilirlik tablosu

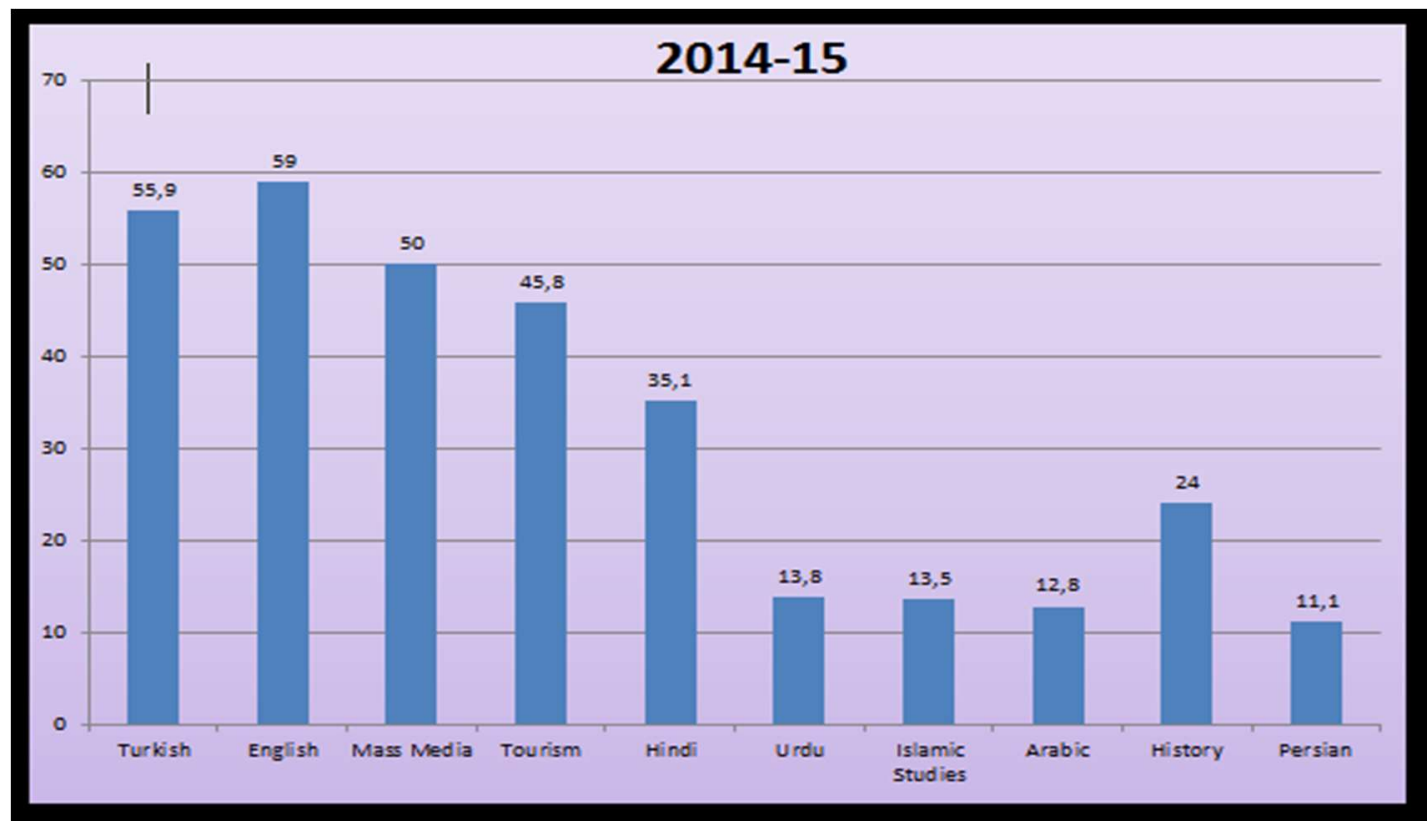

\section{8) Mezunlar nerelerde istihdam ediliyor? İs olanakları nelerdir?}

Lisans mezunu öğrenciler yükseköğretim için burslu ya da burssuz şeklinde Türkiye’ye gelme tercihinde bulunmaktadır. Ancak gelmek istemeyen veya Sertifika, Diploma, Yüksek Diploma programlarından mezun olmuş ya da hâlâ devam eden bazı öğrenciler, Hindistan'da çeşitli özel (uluslararası ticaretle meşgul olan) -Amazon, HP, İndia TV, Wipro, Oracle, Turkish Airways, TCS, Binary Sementic Ltdşirketlerde ekonomik olarak oldukça iyi şartlarda istihdam edilmektedirler.

\section{9) Seçmeli yabanci dil dersi olarak Jawaharnal Nehru'da Türkçe}

Hindistan'ın Delhi eyaletinde bulunan bir başka üniversite, Jawaharnal Nehru'da da Yunus Emre Enstitüsünün protokolü çerçevesinde seçmeli ders olarak Türkçe yer almakta ve öğrenciler tarafindan tercih edilmektedir. İçinde bulunduğumuz dönem itibariyle, farklı bölümlerden yaklaşı 200 öğrenci seçmeli ders olarak Türkçe'yi tercih etmiştir. Bu öğrencilerin ağırlıklı olarak Arapça, İngilizce, Farsça gibi dil ve edebiyat bölümlerini okuyan öğrenciler olduğu dikkati çekmektedir

\section{Sonuç}

Hindistan'ın Jamia Millia İslamia üniversitesi 2006'dan bu yana TíkA ve Yunus Emre Enstitüsü ile beraber Türkçeye büyük hizmetler sunmaktadır. Hindistan'da Türkoloji bölümü Sertifika ile başlamış ve bugün lisans düzeyinde eğitim vermektedir. Bölüm açılır açılmaz öğrencilerin ilgisini çekmeyi başarmıştır. Beşeri bilimler ve yabancı diller fakültesi içinde mezuniyetten sonra iş bulma imkanı sağlayacak birinci bölüm olmuştur. Bu bölüm Hindistan ile Türkiye arasındaki ticaret, teknoloji, sanat gibi hassas konularda önemli rol oynayacaktır. Aynı zamanda Hindistan kütüphanelerinde tozlanmaya mahkum olan dev eserlerin yeniden dünyaya tanıtılmasına firsat sunulmuş olacaktır. 2006'dan bu yana bu bölüm çok hızlı bir şekilde hedefine doğru ilerlemektedir. Yüksek lisans açılması yönünde çalışmalara başlanmış, üniversitenin yönetmelikleri çerçevesinde hazırlıklar sona ermiş olup bir yıl sonra açılması öngörülmektedir. İlgili Senato kararının olumlu yönde çıkması durumunda, Türk Dili Koordinatörlügüu, 
2020-2021 dönemi için, Yüksek Lisans Programına öğrenci kabul etmeyi hedeflemektedir. Üniversite içindeki genel yapıyı ve öğrencilerin algısını göz önünde tutarak şu söylenebilir ki, ancak böylece bölüm hüviyetini de tam anlamıyla kazanmış olacaktır. Bölümün durumunu görünce Hindistan'da Türkçe eğitiminin geleceğinin çok parlak olacağını söyleyebiliriz.

\section{Kaynakça}

3 Jamia students get Turkish scholarships https://www.indiatoday.in/education-today/news/story/3jamia-students-get-turkish-scholarships-1590489-2019-08-22 (son erşim tarihi: 6.07.2019)

A.U. Asif. Chauthi Dunıya, Mayıs 16, 2017, http://urdu.chauthiduniya.com/ (son erişim tarihi 20-o82019)

Alam, M. (2017, 07 Mayıs). Türk Dili ve Edebiyatı Programı koordinatörlügünün verileri, JMI Üniversitesi.

Bilkan, A. F. (1998). Hindistan'da Gelişen Türk Edebiyatı. Ankara: Türk Tarih Kurumu Basımevi.

Bokuleva, Bota., Avakova, Rauşangül, Abeldayev, Jenisbek. (2012). Türk Kültürünün Hindistan Uygarlığına Etkisi. Türk Dünyası Đncelemeleri Dergisi, XII/1, 441-454.

Husain, Shakir. (2018, o8 Eylül). Turkey Ready To Fund Turkish Language Centre At Jamia. BW Businessworld.

İndia-Turkey Relation2018, http://www.indembassyankara.gov.in/page/relation/ (son erşim tarihi: 1.07.2019)

Jamia News https://www.facebook.com/1466028126807128/posts/1903306363079300/?substory_ index $=0$ (son erşim tarihi: 1.08.2019)

Macun, İnci. (1990). Hindistan'da Türk-Müslüman Mimari. Ankara Üniversitesi Dil ve Tarih- Coğrafya Fakültesi Degisi, 1-2

Malkoç, E. (2016). 20.Yüzyılın ikinci yarısında Türkiye ile Hindistan’nn siyasi ilişkileri. Avrasya Incelemeleri Dergisi, $\mathrm{V} / 1,110-111$

Prospectus- Jamia Millia İslamia 2019-2020, http://jmicoe.in/pdf18/Prospectus_2019-20-new.pdf (son erşim tarihi: 20.07.2019)

Six Jamia Millia Islamia students from B.A. (Hons) Turkish Language and Literaturehave been awarded full scholarships by the state of Turkey to pursue further studies in Turkey. https://www.facebook.com/turkishlanguageandliterature/ (son erşim tarihi: 20.08.2019)

Turkey Ready To Fund Turkish Language Centre At Jamia, o8 september 2016 http://www.businessworld.in/article/Turkey-Ready-To-Fund-Turkish-Language-Centre-AtJamia/o8-09-2016- (son erşim tarihi: 10.08.2019)

Türkiye-Hindistan Siyasi İlişkileri http://www.mfa.gov.tr/turkiye-hindistan-siyasi-iliskileri.tr.mfa (son erşim tarihi: 15.08.2019)

http://www.indembassyankara.gov.in/page/relation.

https://www.facebook.com/turkishlanguageandliterature.

http://www.mfa.gov.tr/turkiye-hindistan-siyasi-iliskileri.tr.mfa.

https://www.rteurdu.com/aid-documents-of-the-zamindar-newspaper-lahore-t-ottoman-empire. 